\title{
ANALISIS PENGARUH BENTUK DAN LOKASI BUKAAN PADA BALOK TINGGI MENGGUNAKAN METODE ELEMEN HINGGA
}

\author{
Anthony Fariman ${ }^{1}$ dan Leo S. Tedianto ${ }^{2}$ \\ ${ }^{1}$ Program Studi Sarjana Teknik Sipil, Universitas Tarumanagara, Jl. Letjen S. Parman No.1 Jakarta \\ anthony.325160020@stu.untar.ac.id \\ ${ }^{2}$ Program Studi Sarjana Teknik Sipil, Universitas Tarumanagara, Jl. Letjen S. Parman No.1 Jakarta \\ leotedi@gmail.com
}

Masuk: 02-07-2020, revisi: 09-07-2020, diterima untuk diterbitkan: 04-08-2020

\begin{abstract}
Reinforced concrete deep beam is one of the special structures that can carry quite a big load and generally used as a transfer girder, offshore structure, wall structure, and foundation. The appearance of openings in deep beams can facilitate AC pipelines, plumbing pipes, cable networks, etc. The existence of openings in deep beams can provide a few side effects such as geometric discontinuity, reduced strength of the deep beams, and stresses concentration will emerged around the openings. The purpose of this research is to analyze the effects from the existence of openings in deep beams on two supports (hinge and roller) and loaded by concentrated load in midspan then variate the shape of openings (square, rectangle, and circle) and location of the openings. The analysis will be assisted by Midas FEA which is a finite element based program and modelling will be executed in three dimensional solid elements. The result of this analysis showed that the existence of the openings in deep beams can cause stresses to increase significantly high by $11380 \%$ at the rectangular opening. The location of the openings close to the mid-span of the deep beams also affect the amount of the stresses that occurs.
\end{abstract}

Keywords: deep beams; openings; reinforced concrete; finite element; Midas FEA

\begin{abstract}
ABSTRAK
Balok tinggi beton bertulang merupakan salah satu struktur khusus yang dapat memikul beban cukup besar dan umumnya digunakan sebagai transfer girder, struktur lepas pantai, struktur dinding, dan pondasi. Kehadiran bukaan pada balok tinggi dapat memfasilitasi jalur saluran AC, saluran pipa, jaringan kabel dan lain-lain. Dengan adanya bukaan pada balok tinggi dapat memberikan beberapa efek samping yaitu terjadinya diskontinuitas geometri, berkurangnya kekuatan dari balok, dan timbulnya konsentrasi tegangan di sekitar bukaan. Penelitian ini bertujuan untuk menganalisis efek dari kehadiran bukaan pada balok tinggi di atas dua perletakan (sendi-rol) dan dibebani beban terpusat di tengah bentang balok lalu memvariasikan bentuk bukaan (persegi, persegi panjang, dan lingkaran) dan lokasi bukaan. Analisis akan dibantu dengan Midas FEA yang merupakan program berbasis elemen hingga dan pemodelan dilakukan dengan elemen solid tiga dimensi. Hasil dari analisis ini menunjukkan bahwa kehadiran bukaan pada balok tinggi menyebabkan kenaikan tegangan secara signifikan sebesar $11380 \%$ pada bukaan persegi panjang. Lokasi dari bukaan yang mendekati daerah tengah bentang balok juga sangat mempengaruhi besarnya tegangan yang terjadi.
\end{abstract}

Kata kunci: balok tinggi; bukaan; beton bertulang; elemen hingga; Midas FEA

\section{PENDAHULUAN}

Seiring perkembangan zaman, tuntutan menciptakan bangunan yang kuat dan tahan lama terhadap berbagai macam beban dan kondisi yang dihadapi tidak cukup dengan menggunakan sistem struktur yang sederhana, perlu menggunakan system struktur yang khusus. Salah satu elemen struktur yang khusus tersebut adalah balok tinggi beton bertulang. Balok tinggi ini memiliki sifat yang berbeda dibandingkan dengan balok biasa, serta memiliki banyak kegunaan. Balok tinggi pada umumnya digunakan sebagai elemen struktur penyalur beban seperti transfer girder, pile cap, dan beberapa struktur dinding (Wight, 2016).

Balok Tinggi merupakan struktur yang dapat memikul beban yang cukup besar. Menurut persyaratan beton struktural untuk bangunan gedung, balok tinggi adalah komponen struktur yang dibebani pada salah satu mukanya dan ditumpu pada muka yang berlawanan sehingga strat tekan dapat membentuk di antara beban dan tumpuan. Balok dinyatakan sebagai balok tinggi jika bentang bersih, ln, sama dengan atau kurang dari empat kali tinggi 
komponen struktur keseluruhan, $h(\ln \leq 4 h)$ (SNI 2847, 2013). Untuk lebih jelasnya dapat dilihat pada gambar dibawah ini.

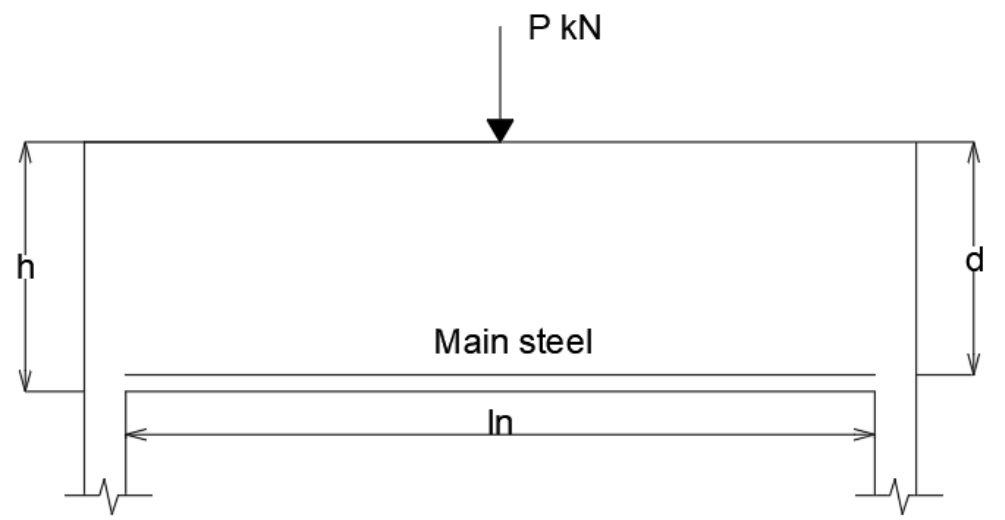

Gambar 1. Bentang Bersih ln, dan tinggi komponen struktur, h (F.K.Kong, 2003)

Untuk memenuhi suatu kebutuhan yang mendesak atau terpaksa, suatu elemen struktur bisa saja dimodifikasi, dalam hal ini adalah memberi bukaan atau lubang pada struktur tersebut. Memberi bukaan pada balok bisa menjadi salah satu solusi untuk mencapai keuntungan ekonomis pada gedung-gedung tinggi dengan memberi ruang vertikal lebih. Bukaan yang biasa terdapat pada sebuah balok digunakan untuk memfasilitasi saluran AC, kabel listrik, kabel jaringan komputer, saluran pipa, dan lain-lain. Efek dari bukaan pada balok adalah kekuatan dari balok akan berkurang dan akan terjadi defleksi yang lebih besar karena terjadi reduksi momen inersia dari bukaan tersebut. Selain itu perlu penanganan yang lebih pada daerah sekitar bukaan seperti menambahkan jumlah tulangan disekitar bukaan karena terjadi konsentrasi tegangan yang besar disekitar bukaan.

Pada penelitian ini akan dilakukan studi kasus tentang balok tinggi dengan bukaan menggunakan bantuan program Midas FEA yang merupakan program berbasis metode elemen hingga. Studi kasus yang akan dilakukan adalah memodelkan suatu balok tinggi yang akan diberi 2 buah bukaan dimana bukaan tersebut akan divariasikan bentuk dan lokasi bukaannya. Tujuan dari penelitian ini adalah:

- Untuk mengetahui pengaruh dari bentuk dan lokasi bukaan pada balok tinggi

- Untuk mengetahui bentuk dan lokasi bukaan yang kritis

- Untuk mengetahui presentase kenaikan tegangan akibat adanya bukaan pada balok tinggi

- Untuk mengetahui besar tegangan yang terjadi pada tengah bentang balok tinggi di setiap bentuk dan lokasi bukaan yang berbeda

\section{METODE PENELITIAN}

\section{Pemodelan pada Midas FEA}

Pemodelan balok tinggi pada Midas FEA akan dilakukan dengan elemen solid tiga dimensi. Jenis elemen yang digunakan pada balok tinggi (beton) adalah elemen linier hexahedron 8 nodal. Elemen ini umumnya menghasilkan hasil tegangan dan regangan yang lebih akurat (FEA, 2011). Untuk tulangan, jenis elemen yang digunakan adalah elemen linier satu dimensi (truss element). Midas FEA menghadirkan fitur elemen satu dimensi khusus (reinforcement) untuk memodelkan tulangan, untuk lebih jelasnya dapat dilihat pada gambar 2.
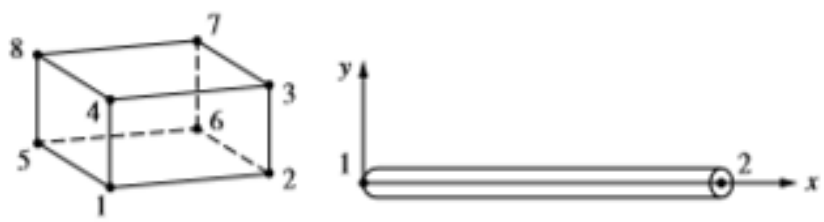

Gambar 2. Elemen linier hexahedron (kiri) dan elemen linier satu dimensi (kanan) (Logan, 2007) 


\section{Spesifikasi pada balok tinggi}

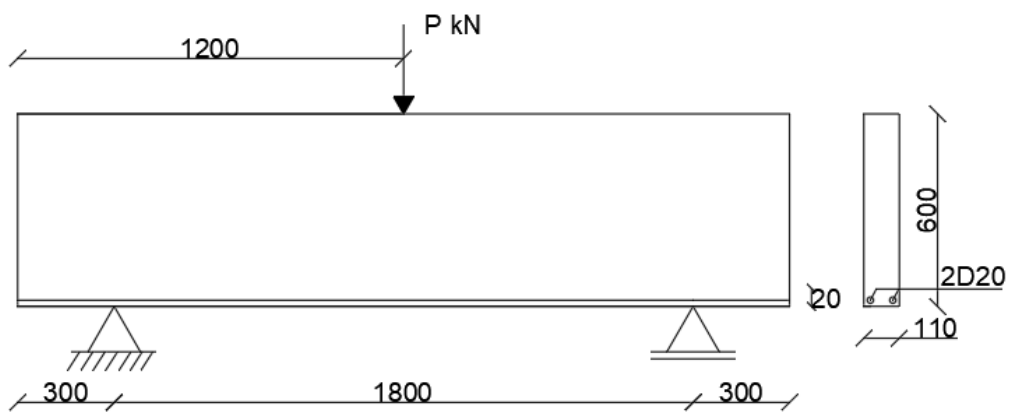

Gambar 3. Spesifikasi balok tinggi (Alsaeq, 2013)

Tabel 1. Tabel spesifikasi balok tinggi

\begin{tabular}{ll}
\hline Spesifikasi & Penjelasan spesifikasi \\
\hline Dimensi Balok & 2400x600x110 mm \\
Perletakan & Sendi dan rol \\
Posisi perletakan & $300 \mathrm{~mm}$ dari kedua ujung balok \\
Pembebanan & $\begin{array}{l}\text { Beban terpusat P kN di tengah } \\
\text { bentang }\end{array}$ \\
Tulangan tarik & $2 \mathrm{D} 20$ \\
Selimut beton & $20 \mathrm{~mm}$ \\
f'c beton & $94 \mathrm{MPa}$ \\
fy tulangan & $500 \mathrm{MPa}$
\end{tabular}

Spesifikasi balok yang digunakan pada setiap kasus akan sama seperti pada gambar 3 dan tabel 1

\section{Prosedur penelitian}

Pada studi kasus ini pemodelan yang dilakukan akan dikelompokkan menjadi 4 kasus, yaitu kasus 1, kasus 2, kasus 3 dan kasus 4 yang merupakan balok tinggi dengan bukaan. Yang menjadi pembeda pada setiap grup adalah bentuk dari bukaan tersebut. Luas penampang bukaan pada setiap grup akan sama yaitu sebesar $1 \%$ dari luas badan balok (Luas penampang bukaan $=2400 \times 600 \times 1 \%=14400 \mathrm{~mm}^{2}$ ).

Bentuk bukaan dari kasus 1 (gambar 4) adalah persegi (a), kasus 2 adalah persegi panjang dengan sisi panjang searah sumbu y (b), kasus 3 adalah persegi panjang dengan sisi panjang searah sumbu x (c), dan kasus 4 adalah lingkaran (d).

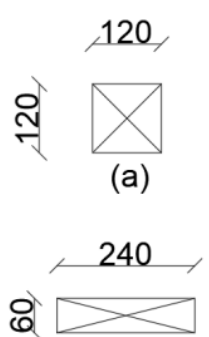

(c)

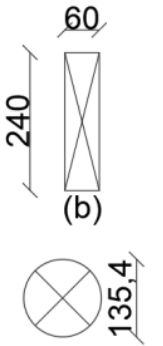

(d)

Gambar 4. Bentuk bukaan pada kasus 1,2,3, dan 4 (Alsaeq, 2013)

Pada setiap kasus akan terdapat 15 model balok tinggi dengan posisi bukaan yang berbeda-beda. Total model sebanyak 60. Jumlah bukaan yang terdapat pada balok adalah 1 buah bukaan pada setiap sisi balok dengan posisi yang simetris. Posisi bukaan akan disimbolkan dengan d1 (jarak horizontal) dan d2 (jarak vertikal). d1 dan d2 
merupakan jarak dari suatu batas ke titik berat dari bukaan tersebut. Untuk lebih jelasnya akan ditampilkan pada tabel dan gambar di bawah ini (Gambar 5 sebelah kiri).
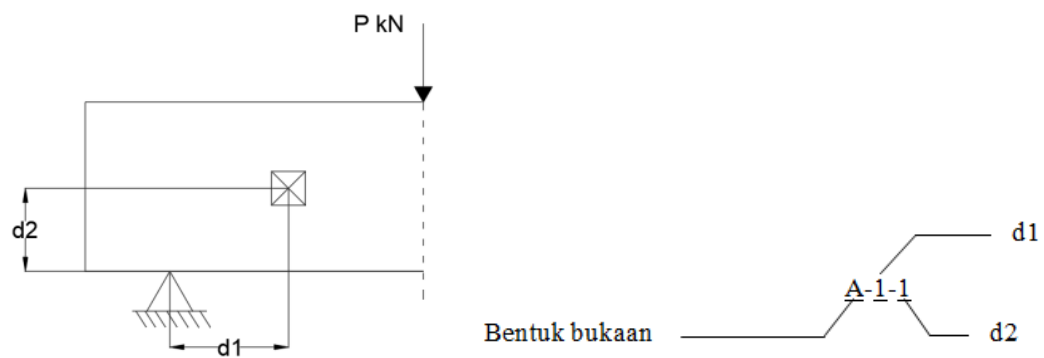

Gambar 5. d1 dan d2 pada balok tinggi

Untuk mempermudah pemahaman pada setiap pemodelan balok tinggi, akan dibuat kode pada setiap pemodelan dengan kode seperti di Gambar 5 sebelah kanan.

Alfabet pertama A menunjukkan bentuk dari bukaan balok tinggi pada kasus 1 sampai dengan kasus 4. Satu digit angka di tengah menunjukkan nilai dari $\mathrm{d} 1 \mathrm{(mm})$ dan satu digit angka di belakang menunjukkan nilai dari d2 $(\mathrm{mm})$. Pada tabel 2 di bawah ini akan ditampilkan daftar kode yang digunakan pada setiap kasus.

Tabel 2. Daftar kode untuk pemodelan

\begin{tabular}{cc}
\hline Bentuk Bukaan & Kode \\
\hline persegi & A \\
persegi panjang $(y)$ & B \\
persegi panjang (x) & C \\
Lingkaran & D \\
\hline
\end{tabular}

\begin{tabular}{cc}
\hline Nilai d1 & Kode \\
\hline 120 & 1 \\
240 & 2 \\
360 & 3 \\
480 & 4 \\
600 & 5
\end{tabular}

\begin{tabular}{cc}
\hline Nilai d2 & Kode \\
\hline 210 & 1 \\
300 & 2 \\
420 & 3 \\
\hline
\end{tabular}

Keterangan: Persegi panjang (y): persegi panjang dengan sisi terpanjang searah sumbu y (kasus-2)

Persegi panjang (x): persegi panjang dengan sisi terpanjang searah sumbu $\mathrm{x}$ (kasus-3)

Tabel 3. Kode pada kasus-1

\begin{tabular}{cccc}
\hline Model & Kode & $\mathrm{d} 1(\mathrm{~mm})$ & $\mathrm{d} 2(\mathrm{~mm})$ \\
\hline Model 1 & A-1-1 & 120 & \\
Model 2 & A-2-1 & 240 & \\
Model 3 & A-3-1 & 360 & 210 \\
Model 4 & A-4-1 & 480 & \\
Model 5 & A-5-1 & 600 & \\
\hline Model 6 & A-1-2 & 120 & \\
Model 7 & A-2-2 & 240 & \\
Model 8 & A-3-2 & 360 & 300 \\
Model 9 & A-4-2 & 480 & \\
Model 10 & A-5-2 & 600 & \\
\hline
\end{tabular}


Tabel 3. Kode pada kasus-1 (lanjutan)

\begin{tabular}{cccc}
\hline Model & Kode & d1 $(\mathrm{mm})$ & $\mathrm{d} 2(\mathrm{~mm})$ \\
\hline Model 11 & A-1-3 & 120 & \\
Model 12 & A-2-3 & 240 & \\
Model 13 & A-3-3 & 360 & 420 \\
Model 14 & A-4-3 & 480 & \\
Model 15 & A-5-3 & 600 & \\
\hline
\end{tabular}

Tabel 4. Kode pada kasus-2

\begin{tabular}{cccc}
\hline Model & Kode & d1 $(\mathrm{mm})$ & $\mathrm{d} 2(\mathrm{~mm})$ \\
\hline Model 16 & B-1-1 & 120 & \\
Model 17 & B-2-1 & 240 & \\
Model 18 & B-3-1 & 360 & 210 \\
Model 19 & B-4-1 & 480 & \\
Model 20 & B-5-1 & 600 & \\
\hline Model 21 & B-1-2 & 120 & \\
Model 22 & B-2-2 & 240 & 300 \\
Model 23 & B-3-2 & 360 & \\
Model 24 & B-4-2 & 480 & \\
Model 25 & B-5-2 & 600 & \\
\hline Model 26 & B-1-3 & 120 \\
Model 27 & B-2-3 & 240 & 420 \\
Model 28 & B-3-3 & 360 & \\
Model 29 & B-4-3 & 480 & 600 \\
Model 30 & B-5-3 & & \\
\hline
\end{tabular}

Tabel 5. Kode pada kasus-3

\begin{tabular}{cccc}
\hline Model & Kode & d1 $(\mathrm{mm})$ & $\mathrm{d} 2(\mathrm{~mm})$ \\
\hline Model 31 & C-1-1 & 120 & \\
Model 32 & C-2-1 & 240 & \\
Model 33 & C-3-1 & 360 & 210 \\
Model 34 & C-4-1 & 480 & \\
Model 35 & C-5-1 & 600 & \\
\hline Model 36 & C-1-2 & 120 & \\
Model 37 & C-2-2 & 240 & \\
Model 38 & C-3-2 & 360 & 300 \\
Model 39 & C-4-2 & 480 & \\
Model 40 & C-5-2 & 600 & \\
\hline
\end{tabular}


Tabel 5. Kode pada kasus-3 (lanjutan)

\begin{tabular}{cccc}
\hline Model & Kode & d1 $(\mathrm{mm})$ & $\mathrm{d} 2(\mathrm{~mm})$ \\
\hline Model 41 & C-1-3 & 120 & \\
Model 42 & C-2-3 & 240 & \\
Model 43 & C-3-3 & 360 & 420 \\
Model 44 & C-4-3 & 480 & \\
Model 45 & C-5-3 & 600 & \\
\hline
\end{tabular}

Tabel 6. Kode pada kasus-4

\begin{tabular}{cccc}
\hline Model & Kode & $\mathrm{d} 1(\mathrm{~mm})$ & $\mathrm{d} 2(\mathrm{~mm})$ \\
\hline Model 46 & D-1-1 & 120 & \\
Model 47 & D-2-1 & 240 & \\
Model 48 & D-3-1 & 360 & 210 \\
Model 49 & D-4-1 & 480 & \\
Model 50 & D-5-1 & 600 & \\
\hline Model 51 & D-1-2 & 120 & \\
Model 52 & D-2-2 & 240 & 300 \\
Model 53 & D-3-2 & 360 & \\
Model 54 & D-4-2 & 480 & \\
Model 55 & D-5-2 & 600 & \\
\hline Model 56 & D-1-3 & 120 & \\
Model 57 & D-2-3 & 240 & 420 \\
Model 58 & D-3-3 & 360 & \\
Model 59 & D-4-3 & 480 & \\
Model 60 & D-5-3 & 600 & \\
\hline
\end{tabular}

Selain pemodelan balok tinggi dengan bukaan pada tabel 3, tabel 4, tabel 5, dan tabel 6, akan dibuat juga pemodelan balok tinggi tanpa bukaan (balok tinggi utuh) untuk membandingkan hasil tegangan yang terjadi pada balok tanpa bukaan dengan balok dengan bukaan. Pada kasus ini tegangan yang ditinjau adalah tegangan arah $\mathrm{x}$ pada balok $\left(\sigma_{x}\right)$ yang berada pada tengah bentang balok dan tegangan yang terjadi di sekitaran bukaan.

Untuk tegangan yang terjadi di sekitaran bukaan, akan ditinjau tegangan yang nilainya kritis (maksimum). Tegangan yang ditinjau pada bukaan akan dibagi menjadi dua yaitu tegangan bagian eksterior (dekat sisi luar balok) dan tegangan bagian interior (dekat sisi dalam balok) seperti pada gambar 6 . Tegangan yang ditinjau juga hanya pada 1 lubang saja pada setiap model karena bersifat simetris.

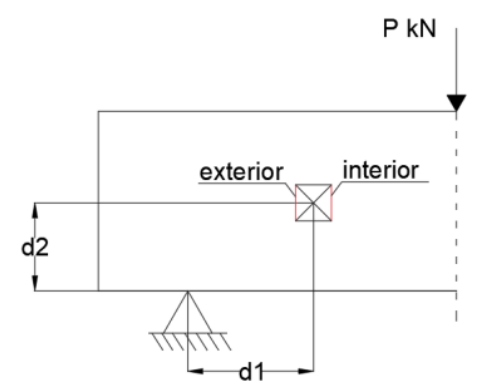

Gambar 6. Posisi eksterior dan interior pada bukaan 
Setelah didapatkan tegangan kritis pada bukaan, kemudian nilai tegangan tersebut akan dibandingkan dengan nilai tegangan yang terjadi pada balok tanpa bukaan di posisi yang berkesinambungan. Kemudian menghitung presentase kenaikan tegangan yang terjadi dengan

$$
\% \text { kenaikan }=\frac{|A|-|B|}{|B|} \times 100 \%
$$

dengan $|A|=$ tegangan balok dengan bukaan dan $|B|=$ tegangan balok tanpa bukaan.

\section{HASIL DAN PEMBAHASAN}

\section{Tegangan pada tengah bentang balok}

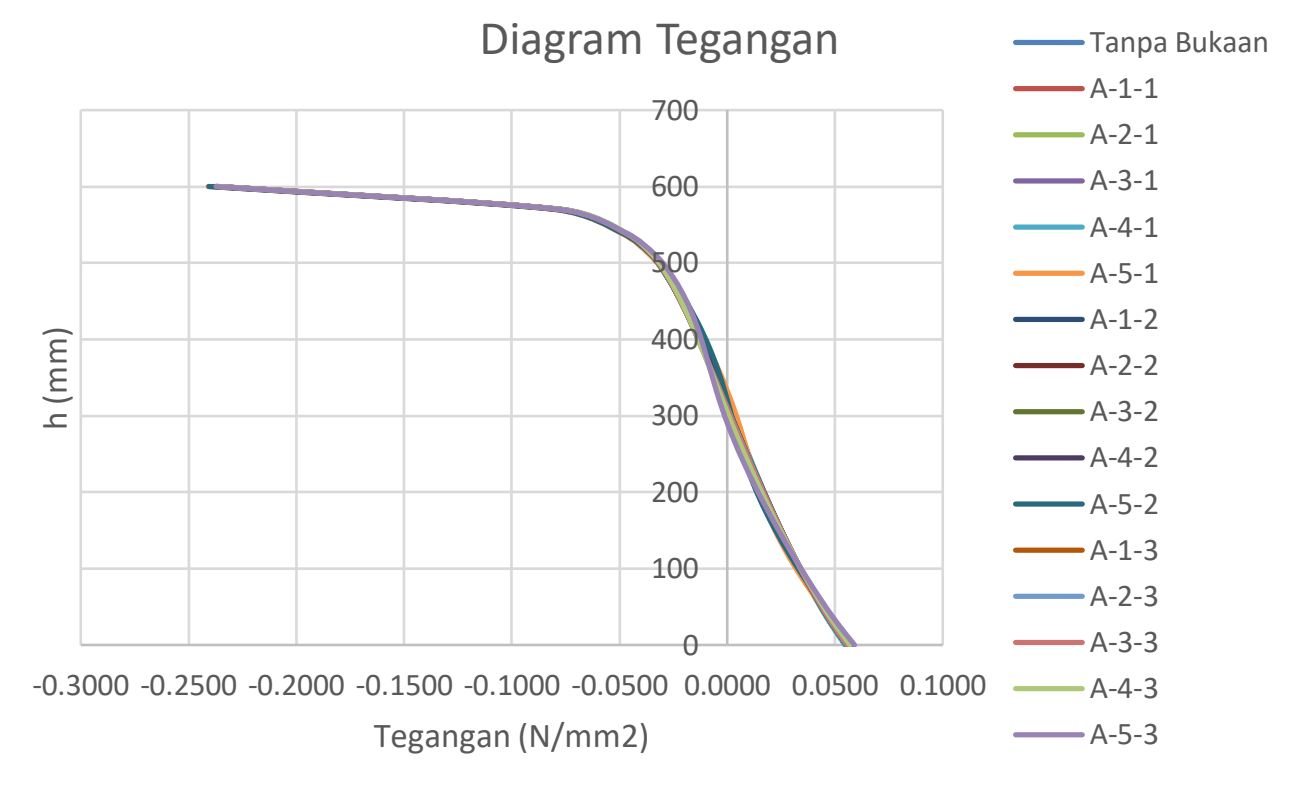

Gambar 7. Diagram tegangan tengah bentang balok kasus-1

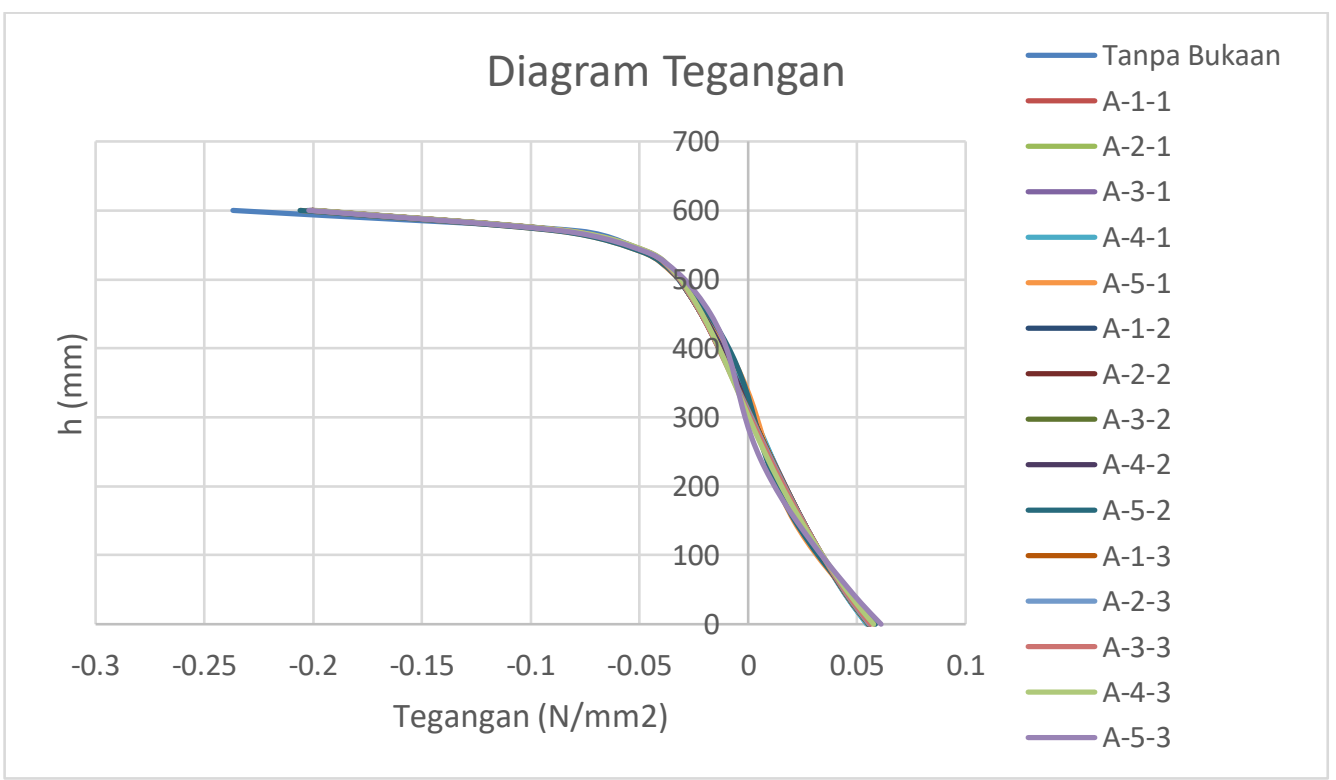

Gambar 8. Diagram tegangan tengah bentang balok kasus-2 


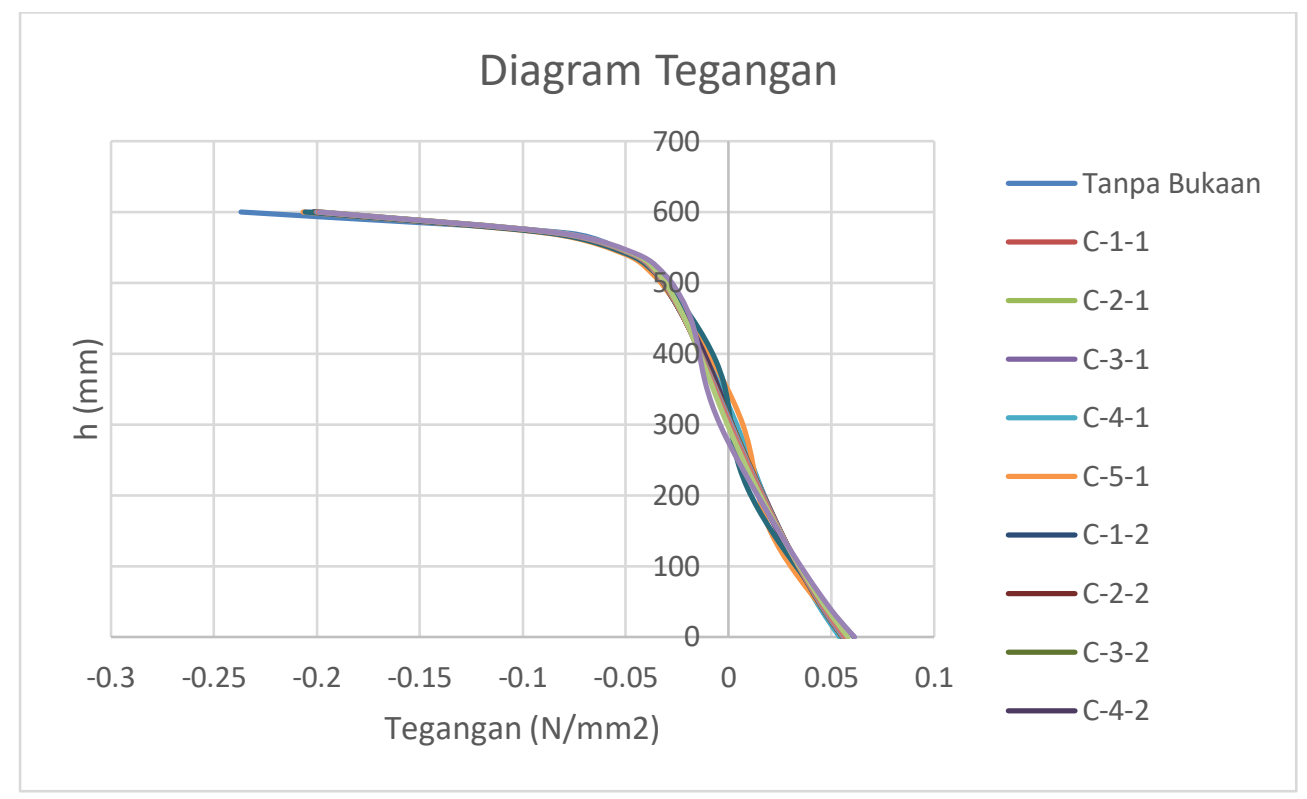

Gambar 9. Diagram tegangan tengah bentang balok kasus-3

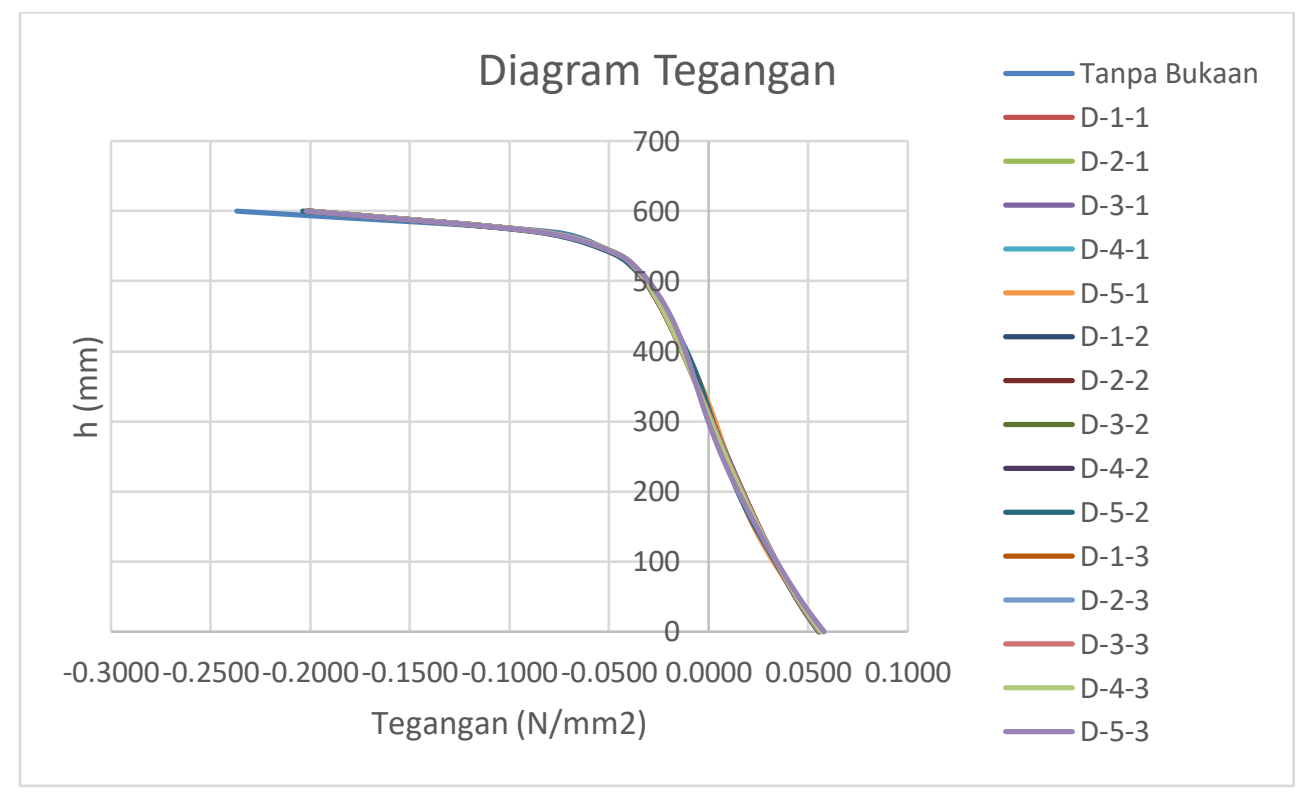

Gambar 10. Diagram tegangan tengah bentang balok kasus-4

Untuk tegangan yang terjadi pada tengah bentang balok pada semua kasus (kasus-1 sampai kasus-4) pada gambar 7 sampai gambar 10, kehadiran bukaan pada balok di segala posisi pada semua kasus (kasus-1 sampai kasus-4) tidak memberikan dampak yang signifikan pada balok. Hal ini dikarenakan diagram tegangan yang diplot dalam bentuk grafik bersifat serupa dan saling bertumpuk satu sama lain. Jadi tegangan tengah bentang yang terjadi pada balok dengan bukaan memiliki sifat yang sama dengan tegangan tengah bentang tanpa bukaan.

\section{Tegangan pada daerah bukaan}

Untuk tegangan yang terjadi pada daerah bukaan, tegangan kritis pada bukaan segi-empat (kasus-1, kasus-2, dan kasus-3) ini terdapat pada sudut-sudut bukaan. Untuk tegangan kritis yang bersifat tarik berada pada bukaan interior sudut atas dan bukaan eksterior sudut bawah. Sedangkan tegangan kritis yang bersifat tekan berada pada bukaan interior sudut bawah dan bukaan eksterior sudut atas seperti pada gambar 11. Sifat tegangan yang sejenis (tarik-tarik atau tekan-tekan) terjadi bersebrangan diagonal pada bukaan. 


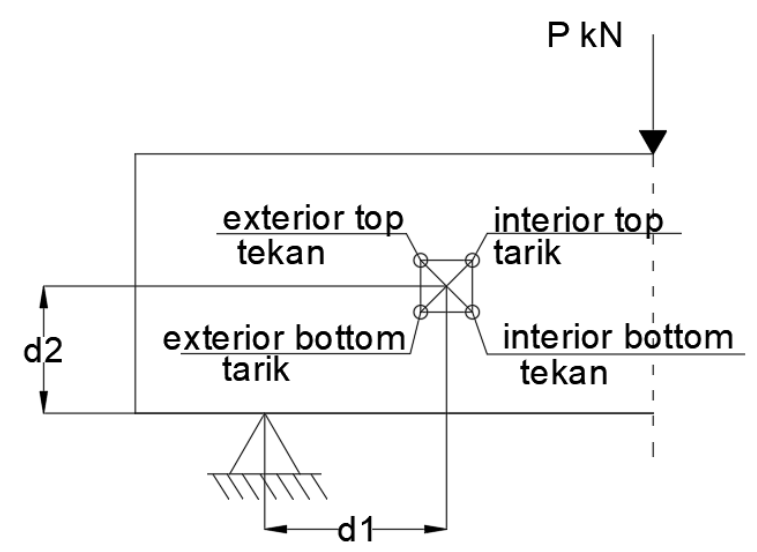

Gambar 11. Lokasi tegangan kritis pada bukaan segi-empat

Untuk bentuk bukaan lingkaran (kasus-4), tegangan tarik kritis terjadi pada bukaan interior $108^{\circ}$ sampai $144^{\circ}$ dan bukaan eksterior $0^{\circ}$ sampai $54^{\circ}$. Tegangan tekan kritis terjadi pada bukaan interior $36^{\circ}$ sampai $72^{\circ}$ dan bukaan eksterior $126^{\circ}$ sampai $180^{\circ}$ (gambar 12 ).

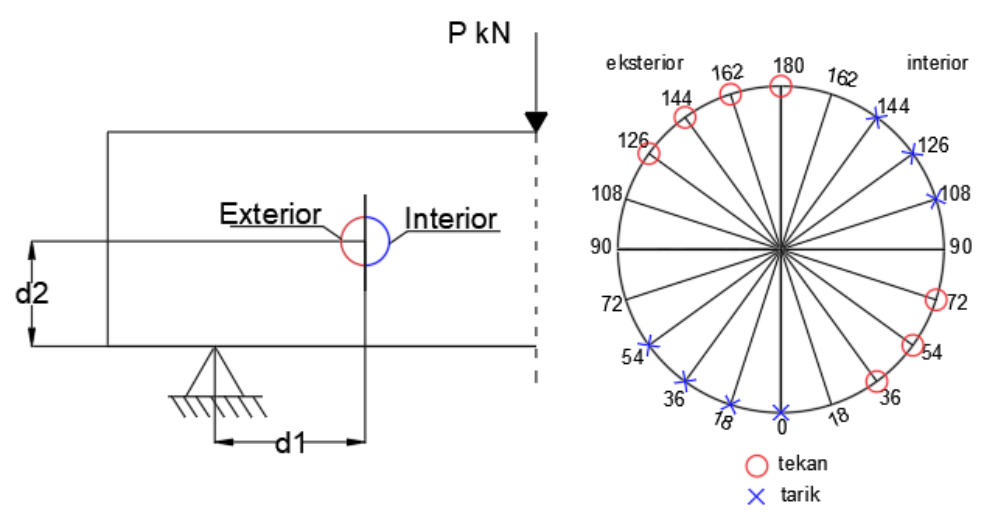

Gambar 12. Lokasi tegangan kritis pada bukaan lingkaran

Nilai tegangan pada bukaan dipengaruhi oleh posisi dari bukaan tersebut. Jika bukaan tersebut semakin mendekati daerah tengah bentang balok, maka tegangan yang terjadi pada bukaan akan bertambah besar. Seperti diketahui bahwa momen maksimum pada balok di atas dua perletakan dan dibebani beban terpusat di tengah akan terjadi pada bagian tengah bentang balok. Di bawah ini merupakan contoh bentuk tegangan yang terjadi di sekitar bukaan pada kasus-1 sampai kasus-4 (gambar 13).

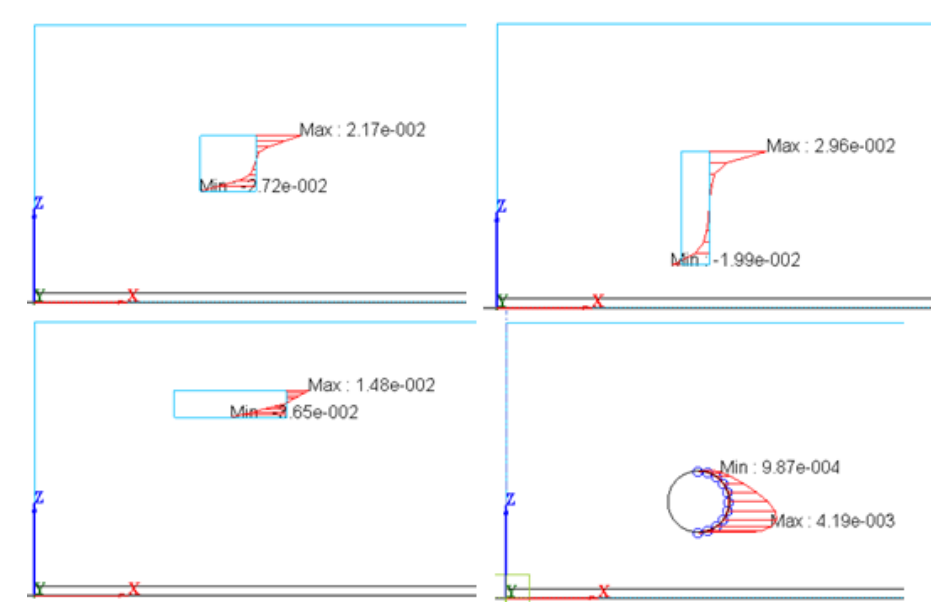

Gambar 13. Tegangan di sekitar bukaan pada kasus-1 sampai kasus-4 
Nilai tegangan pada bukaan yang maksimum pada kasus-1 sampai dengan kasus-4 merupakan bukaan yang paling dekat dengan tengah bentang balok yang dapat dilihat pada tabel 7 di bawah ini

Tabel 7. Tegangan maksimum pada bukaan kasus-1 sampai kasus-4

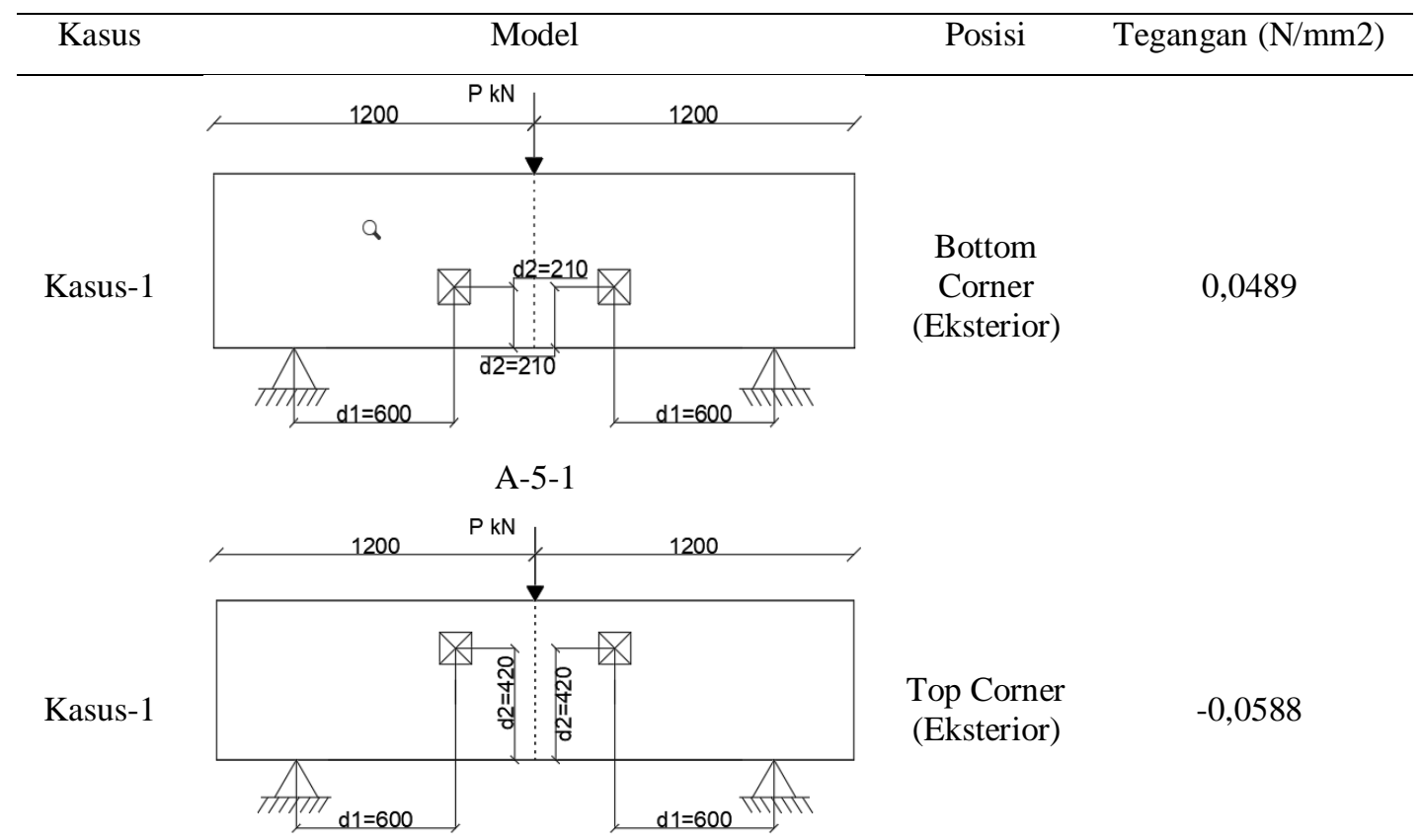

A-5-3

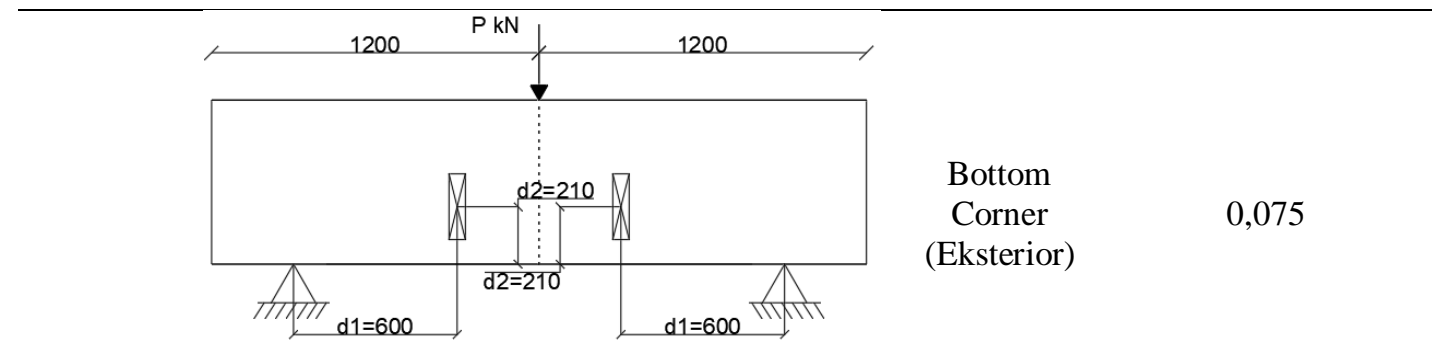

Kasus-2

B-5-1

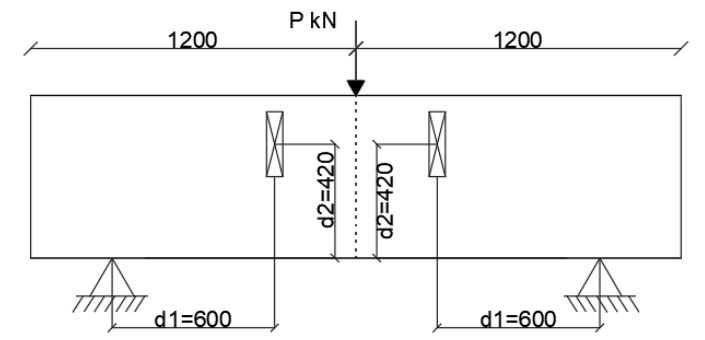

Top Corner

(Eksterior)

$-0,1021$

B-5-3

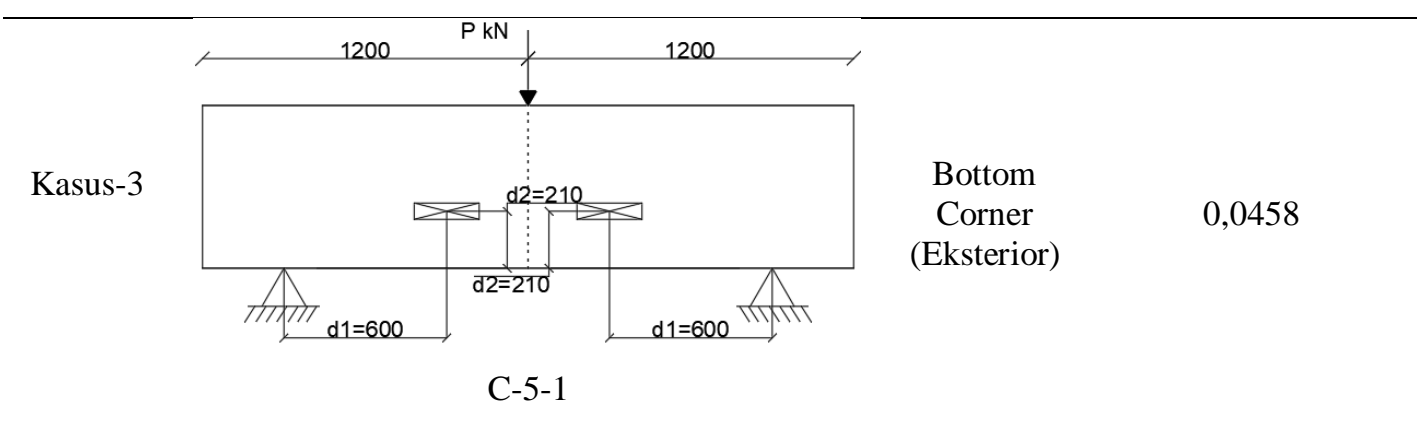


Tabel 8. Tegangan maksimum pada bukaan kasus-1 sampai kasus-4 (lanjutan)

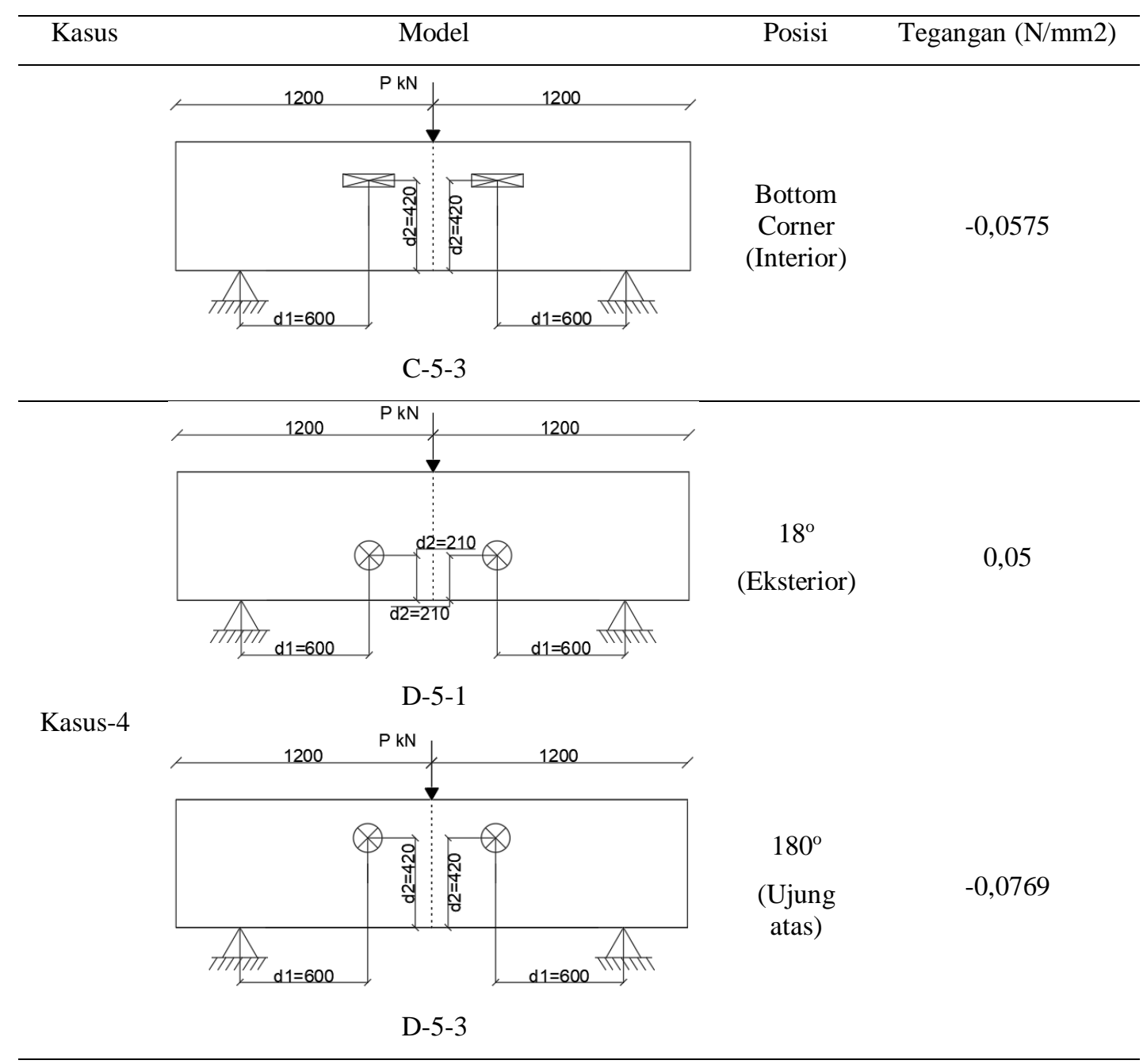

Keterangan : Nilai (+) pada tegangan bersifat tarik

Nilai (-) pada tegangan bersifat Tarik

Presentase kenaikan tegangan paling besar jika lokasi kritis pada bukaan mendikati garis netral dari balok. Nilai tegangan pada balok tinggi pada daerah garis netral sangat kecil (mendekati nol) dan kehadiran bukaan pada balok memberikan suatu daerah konsentrasi tegangan sehingga presentase kenaikan tegangan akan sangat tinggi seperti yang diperlihatkan pada tabel 8 .

Tabel 9. Presentase kenaikan tegangan terbesar pada bukaan

Kasus-1


Tabel 10. Presentase kenaikan tegangan terbesar pada bukaan (lanjutan)

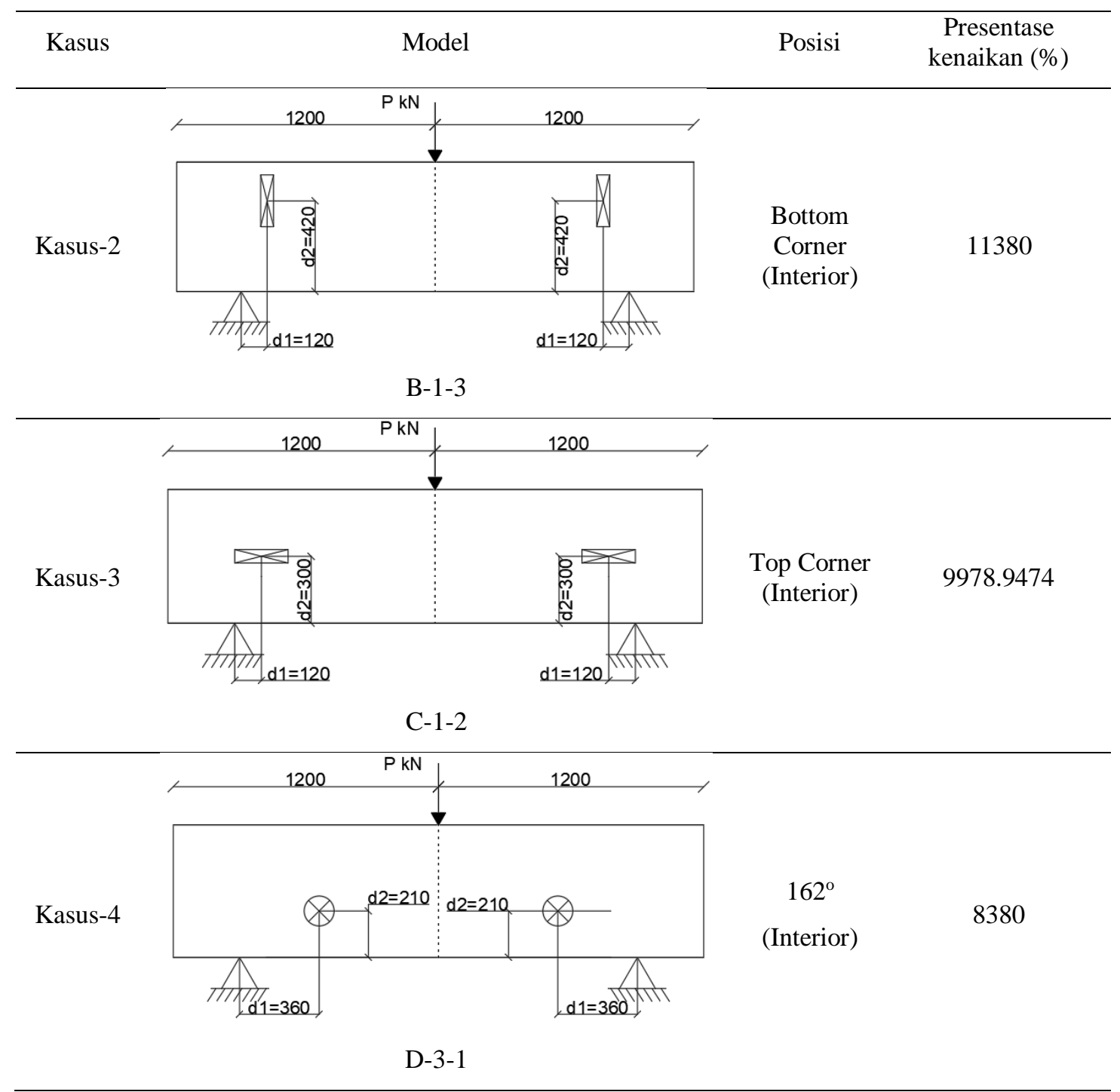

\section{KESIMPULAN DAN SARAN}

\section{Kesimpulan}

1. Bentuk dan lokasi bukaan tidak mempengaruhi tegangan yang terjadi pada tengah bentang balok karena lokasi bukaan tidak berada di tengah bentang balok.

2. Tegangan kritis yang terjadi pada bentuk bukaan segi empat (kasus-1 sampai kasus-3) terdapat pada sudutsudut bukaan sedangkan pada bukaan lingkaran (kasus-4) terdapat pada daerah ujung atas dan ujung bawah bukaan.

3. Lokasi bukaan paling kritis adalah yang paling dekat dengan tengah bentang balok (pada d1=600 mm) karena tegangan pada bukaan akan semakin besar jika lokasi bukaan mendekati daerah tengah bentang balok.

4. Bentuk bukaan yang paling kritis adalah bentuk bukaan dari kasus-2 (persegi panjang dengan sisi terpanjang searah sumbu y) dengan nilai tegangan tarik 0,075 pada B-5-1 bottom corner (eksterior) dan tegangan tekan 0,1021 pada B-5-3 bottom corner (eksterior).

5. Presentase kenaikan tegangan akan semakin besar jika lokasi kritis dari bukaan dekat dengan garis netral dari balok.

6. Presentase kenaikan tegangan terbesar terjadi pada kasus-2 B-1-3 (bukaan persegi panjang dengan sisi terpanjang searah sumbu y) dengan nilai tegangan sebelum adanya bukaan sebesar 0,0003 dan tegangan setelah adanya bukaan sebesar 0,0287 dengan presentase kenaikan $11380 \%$. 


\section{Saran}

1. Melakukan pembebanan yang bervariasi seperti beban merata, menambah jumlah beban, memperhitungkan berat sendiri balok, memberi beban aksial(kombinasi lentur dan aksial).

2. Menggunakan elemen kuadratik dalam proses diskritisasi.

3. Menambah variasi bentuk bukaan, ukuran bukaan, dan jumlah bukaan.

4. Menggunakan tulangan tekan dan tulangan geser dalam pemodelan balok.

\section{DAFTAR PUSTAKA}

Alsaeq, Haider M. "Effects of Opening Shape and Location on Structural of R.C. Deep Beams with Openings." World Academy of Science, Engineering and Technology International Journal of Civil and Enviromental Engineering (2013): 494-499.

F.K.Kong. Reinforced Concrete Deep Beams. New York: Taylor \& Francis Books, Inc, 2003.

FEA, Midas. Analysis and Algorithm midas FEA manual. 2011.

Logan, Daryl L. A First Course In The Finite Element, Fourth Edition. Ontario: Thomson, 2007.

Badan Standardisasi Nasional. SNI 2847:2013. Persyaratan Beton Struktural untuk Bangunan Gedung. Bandung: Badan Standardisasi Nasional, 2013.

Wight, James K. Reinforced Concrete Mechanics and Design Seventh Edition. New Jersey: Pearson, 2016. 
JMTS: Jurnal Mitra Teknik Sipil

Vol. 3, No. 4, November 2020: hlm 1209-1222

EISSN 2622-545X 